\title{
The Ideology of Student Engagement Research
}

\author{
Alex Buckley
}

University of Strathclyde 


\title{
The Ideology of Student Engagement Research
}

\author{
Abstract \\ In a series of recent papers, Nick Zepke has criticised those researching student engagement \\ in higher education for uncritically supporting neoliberalism. The current highly politicised \\ nature of higher education means that clarity about the political implications of \\ engagement research is crucial. This conceptual paper argues that in focusing on literature \\ on students' engagement in learning, Zepke overlooks another substantial body of \\ engagement literature, on students' participation in decisions about learning and teaching. \\ By exploring the political alignment of two of the key models used to conceptualise \\ students' engagement in decision-making, the paper argues that a central element of the \\ research into student engagement is in fact directly opposed to neoliberal approaches to \\ higher education. Student engagement has been deployed both for and against \\ neoliberalism. Zepke has argued that the research on engagement sides with neoliberalism; \\ I show that the research that focuses on student engagement in decision-making supports \\ the opposition.
}

Keywords: student engagement; ideology; neoliberalism; student representation; student feedback

\section{Introduction}

In a series of recent papers, Nick Zepke has offered a vigorous critique of research into student engagement in higher education (Zepke 2014, 2015a, 2015b, 2015c). His accusations include: conceptual confusion; an insufficiently critical approach; a reductionist 'one size fits all' attitude; and an emphasis on pedagogy at the expense of curriculum. However he devotes most space to arguing that student engagement owes its current prominence to an affinity with neoliberal ideas about higher education, such as a focus on performativity and accountability. Paul Trowler has responded (P. Trowler 2015), arguing that Zepke is selective in his reading of the engagement literature, that he overlooks the 
substantial body of engagement literature that does adopt a critical perspective and explicitly rejects neoliberal and consumerist positions.

These are important issues. Student engagement has grown rapidly as a field of research, a policy priority and a focus of educational development efforts. With this new prominence, there is an urgent need for greater clarity about the kinds of conceptual questions that Zepke raises. When the political and economic structures of higher education are in such flux - as they are at the moment in many parts of the world - the focus on the ideological dimension of engagement is welcome. The application of the values of neoliberalism, marketization and consumerisation to higher education is contested, and their perceived impact on learning and teaching practices is controversial. There is considerable resistance to neoliberal values within the academic community, so Zepke's claim that engagement research is aligned with neoliberalism - that it supports neoliberal values, and gains support from them - is surprising and interesting.

It is also the case that student engagement is still enigmatic. Even within the literature (let alone the realms of policy or educational development) there is a lack of clarity about how it should be understood, and even less clarity about what it is for: which (and whose) aims it serves, what the supposed benefits are and how we can tell if it is working (or even if it is happening). Vicki Trowler (2015) argues that the 'chaotic' nature of the student engagement concept allows it to be actively manipulated in order to disguise different underlying interests. Exploring the ideological leaning of engagement research may help with the ongoing project to add some definition to this nebulous concept. For those researchers, educational developers and academic teachers who believe that student engagement is a beneficial force in higher education, the various and sometimes contradictory ways it is understood should be a cause for concern. The exploration of these issues directly benefits teaching practice, insofar as the ideological values behind educational innovations colour their development and implementation.

Nevertheless while the debate between Zepke and Paul Trowler is important, it has so far had limited relevance to a large number of student engagement researchers. Both authors purport to discuss the full range of engagement literature, but they underestimate the dual 
nature of the engagement concept. They take the core literature on engagement to be that which is focused on students' behavioural, emotional and cognitive involvement in their studies, largely from the US (from researchers such as George Kuh). They supplement this core by reference to wider work such as that by Liz Thomas on belonging (Thomas 2012). Paul Trowler goes further by recognising the work on student voice and partnership by Phil Carey (Carey 2013a) and the UK's National Union of Students (NUS 2014). However, both authors overlook the extent to which there is an alternative conception of student engagement, concerned not with students' active involvement in learning activities, but with their role in making decisions about learning and teaching; what is also known as 'student voice'. This is a different concept of student engagement and one that needs independent consideration. Claims cannot easily be transposed from one concept of engagement to the other. The relationship between the two concepts - whether they are two sides of the same coin, or fundamentally different ideas that merely share a name - is an open question (Buckley 2015), but they are certainly distinct enough to warrant separate attention. And in some parts of the world, most notably the UK, it is the conception of engagement as voice that is dominant.

This article will explore the strength of Zepke's criticisms when extended to that alternative body of student engagement research. It will argue that a substantial element of the literature on students' participation in learning and teaching decision-making, far from aligning with neoliberalism, embodies a rejection of neoliberal approaches.

The questions that Zepke raises are important to an understanding of how research and ideology interact, and their extension to this other body of research is a pressing issue. In recent years, the prominence of students' participation in decision-making has increased dramatically and is now a fundamental part of how higher education is understood. There is a growing research literature, but it is struggling to catch up with the developments in government policy, institutional management and teaching practices. Giving students more power in the decisions that affect their education has been celebrated by governments, it has become central to quality assurance mechanisms, and 'student engagement' understood in that way - has become a buzzword featuring in numerous policy documents, conference titles, institutional committees and job descriptions. Students' participation in 
decision-making has also become more visible in efforts to change teaching practice, whether through institutional educational development or sector-wide initiatives.

Students' involvement in decision-making processes plays an important role in the arguments about neoliberal values in higher education. For example, successive UK governments have attempted to deploy prospective students as informed customers that will drive improvements in quality (Brown 2013). On the other hand, student engagement has also been claimed by others including the National Union of Students to be a key element in the opposition to the implementation of neoliberal values (NUS 2014). In the realms of policy and practice, the relationship between students' engagement in decisionmaking and neoliberal values is prominent and contested. The alignment of the research on that topic is therefore of particular interest.

The paper will have a particular focus on UK research, where students' involvement in decision-making is the dominant conceptualisation of engagement.

\section{Student engagement as participation in learning and teaching decision-making}

The concept of student engagement is complex and contested by researchers throughout the English-speaking world. Zepke describes a broad range of interpretations in his discussion of the engagement literature. They include the behavioural/cognitive/affective trinity of Fredericks et al (2004), Barnett and Coate's (2005) focus on ontology and curriculum, the connection with belonging (Thomas 2012), the work around the National Survey of Student Engagement (NSSE) and its derivatives by George Kuh and others (e.g. Kuh 2009), attention to engagement's role in education for social justice (McMahon and Portelli 2004), the sociocultural ecological perspective of Kahu (2013), and Mike Neary's work on students as producers (Neary 2013). In previous work Zepke and Leach (2010) sum up this range of research literature with four 'perspectives': motivation and agency, transactional engagement, institutional support and active citizenship. In Zepke (2015c) he sums up the literature by proposing two different 'meanings' of engagement: “One, a narrow conception of a set of generic student and institutional behaviours in a classroom or online; the other a holistic social-cultural ecosystem in which engagement is the glue linking 
classroom, personal background and the wider community as essential contributors to learning" (p.1320).

Zepke's presentation of the literature is reasonably broad and inclusive, but overlooks a stark distinction in how student engagement is conceptualised. Most of the literature cited by Zepke (and Paul Trowler) focuses on teaching practice and its effect on learning, whether this is the NSSE construct, the connection between engagement and belonging or between engagement and active citizenship. However there is also a body of literature on engagement that explores students' participation in the processes of making decisions about learning and teaching - their involvement in university governance, as sources of feedback, as collaborators on pedagogical improvement projects, curriculum design or the development of new learning activities, etc. This concept of engagement, strongly related to the idea of student voice, is particularly dominant in the UK (and is largely known as student voice outside the UK). Zepke does cite work on the student voice, such as Little et al (2009) and Wimpenny and Savin-Baden (2013). Paul Trowler also includes examples of that literature. However the focus of both authors is on the literature relating to students' direct engagement in learning activities, in and out of the classroom, and they overlook the possibility that literature on student engagement as student voice may require separate attention. In the UK, the growth of interest in student engagement has to a large extent been driven by government and sector agencies, who have explicitly defined it in terms of students' roles in decision-making. In 2009 the Higher Education Funding Council for England - the most prominent funding body for UK higher education and an organisation which has a powerful influence on the direction of policy - funded a study of engagement practices, the scope of which was as follows:

[I]nstitutional and student union processes and practices, such as those relating to student representation and student feedback, that seek to inform and enhance the collective student learning experience, as distinct from specific teaching, learning and assessment activities that are designed to enhance individual students' engagement with their own learning. (Little et al 2009 , emphasis original) 
Similarly, the 2011 UK Government White Paper on Higher Education contained a section entitled 'Student Engagement', which focused on student surveys, collaboration between institutions and student representatives, and student-led teaching awards (BIS 2011). In 2012 the Quality Assurance Agency, responsible for standards in UK higher education, published a new chapter on student engagement in the UK's Quality Code for Higher Education, containing expectations on institutions. It describes two 'domains' covered by the concept of student engagement - 'improving the motivation of students to engage in learning and to learn independently' and 'the participation of students in quality enhancement and quality assurance processes, resulting in the improvement of their educational experience' (QAA 2012, p.2). It then goes on to focus explicitly on the second of those domains, thereby creating an official requirement for UK institutions to do the same. In 2013 the Student Engagement Partnership (TSEP) was created by HEFCE and the National Union of Students as a joint exercise to support the sector in developing student engagement initiatives. They state on their website that their focus is explicitly on student engagement in decision-making. Their 'vision is that students co-produce knowledge, work in partnership with staff and each other to enhance their learning environment and develop their communities, and through their associated representative bodies, actively contribute to the leadership and governance of their institutions. ${ }^{1}$ In addition to these developments in policy and institutional structures, there have been efforts to strengthen students' involvement in local decisions about teaching practice. There have been national initiatives such as the REACT project led by the University of Winchester ${ }^{2}$ and the work on students-aspartners by the Higher Education Academy (Healey et al 2014). There have also been institutional efforts (Campbell 2007).

All of these policy initiatives and developments in teaching practice have ensured that student engagement is predominantly understood in the UK in terms of students' participation in decision-making. This is reflected in the focus of research on student engagement: there is a substantial body of literature exploring issues around students' role in decision-making. There is literature on student involvement in curriculum design (Bovill

${ }^{1}$ http://tsep.org.uk/our-mission-goals/ [accessed October 2016]

2 http://www.studentengagement.ac.uk [accessed 8 October 2017] 
and Bulley 2011, Bovill et al 2011, Bovill and Felton 2016), student representation systems (Carey 2012, Carey 2013a), staff-student partnerships (Seale et al 2015), and co-production (McCulloch 2009, Carey 2013b). There is also literature on broad conceptual issues raised by students' participation in decision-making (Robinson 2012, Little and Williams 2010, Bryson and Hamshire 2016, Neary 2016, Carey 2016). As well as this literature explicitly addressing student engagement, the relative novelty of engagement research (particularly in the UK) means that there is also literature that does not address engagement by name but addresses closely related concepts. A 2010 literature review found that the body of work produced in the UK which could be said to address student engagement traces its roots back to other traditions, such as student feedback, student representation and student approaches to learning, and is less likely to be tagged as 'student engagement' in the authors' keywords' (V. Trowler 2010, p.3). Literature in recent years is more likely to address student engagement explicitly.

The existence of this alternative field of engagement research and body of engagement literature, tied to powerful developments in policy and practice, means that there is a need to extend Zepke's questions beyond the literature on students' engagement with learning activities. It cannot be assumed that Zepke's conclusions transpose straightforwardly to this other literature. It is fundamentally different, particularly in relation to the kinds of political aspects that will weigh most heavily in a consideration of ideological alignment. In the rest of this paper we will explore the strength of two of Zepke's criticisms in the context of the literature on students' participation in decision-making: firstly (and briefly) whether the literature lacks criticality; secondly whether the literature shares an affinity with neoliberalism.

\section{"Engagement seems to escape serious critique"}

Zepke claims that the literature on student engagement offers insufficient criticism of the concept and value of engagement: 'Critique of this complex project [i.e. research on student engagement] has been surprisingly restrained and the question whether it is an uncritically accepted academic orthodoxy arises' (Zepke 2014, p.699). And he believes that 'student engagement' has become a buzzword through being prominent in policy and research 
without being sufficiently interrogated at a conceptual level. He also believes that the engagement construct reflected by NSSE - a self-consciously pragmatic creation (McCormick et al 2013) - has been unquestioningly accepted both as conceptually coherent, and as an appropriate focus for enhancement efforts. Zepke's claim is persuasive, and is echoed by others who have criticized the lack of clarity (Ashwin and McVitty 2015), the overly positive view of engagement (V. Trowler 2010), the 'one-size-fits-all' approach (Baron and Corbin 2012) and even the fundamental coherence of the concept of student engagement (Buckley 2015). He does acknowledge that 'various aspects have been questioned' (p.699) and that 'various aspects of mainstream engagement have been challenged' (Zepke 2015c, p.1312), and he extensively discusses examples of researchers who have in fact criticised aspects of the 'mainstream' view of engagement. But he concludes that 'despite these specific criticisms, the construct as an entity and the research that feeds it have escaped general criticism' (Zepke 2014, p.700).

Paul Trowler objects, claiming that Zepke is 'constructing a straw man on this issue by being selective in representing the literature and by interpreting it one-sidedly' (P. Trowler 2015, p.329). On Trowler's reading there has been a substantial critical literature on student engagement, but then he does also say that 'there is some merit in a claim of lack of criticality in specific areas in the majority of the relevant literature' (p.329). And in previous work he himself even says that " $t$ ] he "student engagement" construct enjoys widespread uncritical acceptance across educational structures' (P. Trowler and V. Trowler 2010, p.14). To justify his claim that Zepke underestimates the volume of critical literature, Paul Trowler cites the finding of Wimpenny and Savin-Baden (2013) that '9 out of 56 papers chosen for close examination had the characteristic of taking "a critical stance"' (Trowler 2015, p.330). The fact that only $16 \%$ of the literature takes a critical stance appears to be entirely compatible with Zepke's claim that 'engagement seems to escape serious critique'. So despite appearances, there is apparent agreement between Zepke and Trowler on the relative lack of literature that explores conceptual problems with student engagement.

\section{'Neoliberalism is a major influence in engagement's rise to prominence'}


Zepke claims that research on student engagement has an important sympathy with neoliberalism:

I argue that student engagement has an elective affinity with neoliberalism.

This has helped it to prominence in educational research and practice.

Similarly, it has led to neoliberal ideas being generally accepted, but not unquestioned, by theorists and researchers working in learning and teaching. (Zepke 2015b, p.704)

Zepke frames his complaint in terms of 'elective affinity', which he borrows from Max Weber's discussion of the connection between capitalism and Protestantism. Paul Trowler takes issue with how Zepke uses the concept of elective affinity. Rather than adjudicate on these issues, I will sidestep that particular debate and talk about a much simpler idea; that there is a basic sympathetic alignment between neoliberal ideas about higher education, and research into student engagement, such that where there are political values contained in the literature on engagement (implicitly or explicitly), they tend to match the political values of neoliberalism. We therefore won't be addressing Zepke's claim exactly as he formulates it, but a modified version that doesn't depend on Weber's notion of elective affinity.

Zepke believes that the engagement literature - as he presents it - aligns with three features of neoliberalism. Firstly, the importance of the marketplace: he sees an alignment between engagement and neoliberalism in the proposed value of engagement to the development of the knowledge and skills that will help students to perform well in the job market. Secondly, he takes engagement research to align with the neoliberal emphasis on performativity - understood as the restriction of value to what can be measured and reported - through the prominent role of metrics and indicators (most notably NSSE) in the engagement literature. Thirdly, and relatedly, there is neoliberalism's connection with accountability and again, Zepke highlights the role of NSSE and the way it is taken as a proxy for quality. Paul Trowler objects that this rests on a partial reading of the engagement literature, that ' $[\mathrm{m}]$ any student engagement researchers challenge the neoliberal market ideology which positions the student as consumer' (Trowler 2015, p.336). 
This paper will transpose the question to the body of literature on students' participation in decision-making, and - as mentioned above - will avoid debates about the appropriate interpretation of the concept of elective affinity. Instead my question will be - taking 'alignment' to mean that the literature expresses fundamental values shared by a neoliberal approach to higher education - does the literature on students' participation in decisionmaking in higher education align with neoliberalism?

The main focus of explicit discussions of neoliberalism in the context of student engagement in decision-making is consumerism, understood as the view that higher education is a transaction between institutions providing a product or service, and students receiving that product or service. This is often linked to the payment mechanism, with students seen as not just receiving but purchasing the product or service. In the UK, increased fees and uncapped student recruitment have added force to the idea of students as consumers. Consumerism encapsulates all three of the elements of neoliberalism highlighted by Zepke: marketization, performativity and accountability. The system encourages students to calculate the returns that their education will yield in the job market. Students are supposed to select institutions and courses on the basis of quantitative information. And institutions are expected to compete on the basis of those metrics, which are taken to capture the quality of provision.

Student participation has a key role in this system. Universities wish to understand and respond to the views of their students for the instrumental reason that they need to maintain or improve their image in the marketplace. Central to the metrics that are supposed to inform consumer behaviour and institutional competition is the National Student Survey, an annual survey of final year students. This is an important sector-level element of the student voice system, but institutions also use internal surveys, course representative structures and students' unions to monitor service provision and focus improvement efforts. In the realm of policy therefore, there is an unambiguous connection between student engagement and neoliberalism (in the form of consumerism). The NSS functions, at least in part, as a consumer satisfaction survey, and more generally, student 
participation in decision-making plays both official and unofficial roles in supporting students' role as consumers in a service transaction.

However, Zepke's claim is not about the realm of policy or practice, but about the body of literature on student engagement in higher education. Paul Trowler notes, 'Zepke is unclear about what exactly it is that has an "elective affinity" with neoliberalism' (Trowler 2015, p.332); whether it is student engagement research, the interest in student engagement in a broader sense, or just the idea of student engagement itself. Nevertheless, it is reasonably clear that Zepke is concerned with the realm of research, understood as the peer-reviewed published literature. So in extending Zepke's claim to the literature on engagement in decision-making, the question is whether that body of peer-reviewed literature shares the values of neoliberalism encapsulated in the concept of consumerism.

At first glance, there is certainly reason to think that the claim is implausible. It is easy to think of recent literature on engagement that is critical of consumerism (e.g. McCulloch 2009), of the market (e.g. Baron and Corbin 2012) and of neoliberalism more generally (e.g. Taylor et al 2012). However, as the exchange between Zepke and Paul Trowler illustrates, it is challenging to persuasively generalise about the ideological inclinations of an entire body of research literature. To make the task more manageable in what follows, I will focus on two of the most prominent conceptual models used for understanding students' participation in decision-making, and explore their ideological affiliations. The focus on these models will only provide evidence for a more restricted claim - limited to the literature that relies on either of these two models - but one that is more robust. The two models selected have had a particularly powerful impact: Sherry Arnstein's 'ladder of participation'; and Michael Fielding's hierarchical model of student voice. They are both powerful analytical tools for understanding engagement, and have been central to efforts to strengthen students' influence in UK higher education. For each model. I will describe it, describe the key literature that applies or draws on it, and explore the model's connection to neoliberal ideas.

\section{Sherry Arnstein's ladder of participation}


Sherry Arnstein's metaphor of a ladder, representing levels of citizen participation in planning decisions in the US, was developed in the late 1960s. Arnstein was concerned with the power that members of ethnic minorities had over decisions about state sponsored urban renewal and poverty reduction initiatives. Arnstein was particularly interested in the 'critical difference between going through the empty ritual of participation and having the real power needed to affect the outcome of the process' (Arnstein 1969, p216). Figure 1 shows the model, with its progression from 'manipulation' to 'citizen control'.

[Figure 1 here]

Arnstein's ladder has had a powerful impact on the literature on student participation in decision-making. Arnstein's basic idea of a progression from less to more 'authentic' varieties of participation is widely referenced (e.g. Freeman and Dobbins 2011, Carey 2012, Freeman 2014). A number of authors have also made substantial attempts to explicitly adapt her model for student engagement in higher education, the earliest and most influential of which is that of Bovill and Bulley (2011), who provide modified labels and example activities for each step on the ladder. They find the ladder useful in exploring questions about 'the desirability and possibility of [active student participation] in curriculum design' (p.9). Phil Carey has also adapted the ladder at length in both Carey (2013a) and (2016). It has been a key model at policy level and in the grey literature (May and Felsinger 2010, NUS-HEA 2010, Healey et al 2014).

Does Arnstein's model have any ideological alignment with respect to neoliberalism or consumerism? The hierarchical element of the ladder is explicitly generated by the allocation of power to the powerless: 'The ladder juxtaposes powerless citizens with the powerful in order to highlight the fundamental divisions between them' (Arnstein 1969, p.217). The explicit aim is social reform: the redistribution of power away from groups such as elected officials and government agencies, and towards ethnic minority groups and residents of areas of poverty. The original model embodies a desire to empower minority and underrepresented groups, through involvement in decision-making about the allocation of public funds: 'the means by which they can induce significant social reform which enables them to share in the benefits of the affluent society' (p.216). The model presents the 
weakest form of participation as 'manipulation': 'Instead of genuine citizen participation, the bottom rung of the ladder signifies the distortion of participation into a public relations vehicle by powerholders' (p.218). The top of the ladder corresponds to citizen control over decision-making, promising to 'counteract the various corrosive political and socioeconomic forces that plague the poor' (p.224).

In the applications of Arnstein's model to student participation in decision-making, the factor that creates the hierarchy is still the level of power possessed by a group taken to traditionally lack influence over the decisions that affect them; in this case, students. The intention behind these uses of Arnstein's model is explicitly to draw attention to issues of power, which is felt to be 'overlooked in official discourse around student engagement' (Carey 2016, p.2). The lower rungs of the ladder are taken to represent the very minimal influence of students over decisions, '[f]or example, students feed back their views to tutors, but never see appropriate changes' (Bovill and Bulley 2011, p.5). It is argued that much of the work characterised as 'student engagement' in policy and practice - such as student surveys, student representative systems, and much of what is mandated by the QAA Quality Code - consists of consultation and sits at the lower levels of the hierarchy. These engagement processes are characterised as reflective of consumerism: 'In the consumerist paradigm, student involvement is limited to individualised feedback, the management of complaints and narrow consultation' (Carey 2016, p.251). Moving up the ladder requires granting more power to students over the decisions that affect them, with the very highest level being students in control, which 'implies the tutor is absent' (Bovill and Bulley 2011, p.6). What generally receives most attention in the literature is not student control, but actually Arnstein's penultimate stage of partnership, in this case between staff and students.

Just as Arnstein presents the upper levels of the ladder as a radical challenge to dominant economic and political structures, so partnership and student control is seen as offering a fundamental challenge to higher education as we know it: 'theories of student engagement should coalesce around the notions of radicalism that are absent in much policy. Authentic student engagement will test how the relationships between students, their universities and civic society are perceived and managed' (Carey 2016, pp.5-6). The political message behind 
the literature that seeks to apply Arnstein's ladder to higher education is thus the realignment of economic and political structures in higher education in order to radically empower students, a group that is currently taken to be disempowered, if not oppressed. In employing the model of the ladder, these researchers explicitly contrast this kind of empowerment with the consumerist model currently dominant, corresponding to the lower rungs of the ladder: 'This partnership is a direct challenge to consumerism and defies managerialism. It fundamentally challenges how students are expected to work with their universities' (Carey 2016, p.251).

\section{Michael Fielding's radical student voice}

Another prominent model is that developed by Michael Fielding in his work on student involvement in the schools sector. It has a broad similarity to Arnstein's ladder model, and there is an indirect link: Fielding (2012) acknowledges a debt to the 'ladder of participation' of Hart (1992), which in turn is explicitly based on Arnstein's work. Fielding is interested in promoting a radical version of student voice, whereby students are genuinely and substantially empowered and tokenism is avoided. His ultimate aim is for schools to actively model forms of direct democracy, and for schools to 'warm to the naming of democracy as a legitimate aspiration to be overtly addressed on a day-to-day basis in the processes and culture of the school' (Fielding 2012, p.49). He is also motivated by a desire for greater clarity in discussions of student voice:

[S]tudent voice is currently popular but one of the perils of popularity is surface compliance. Schools may well feel obliged to be seen to be 'doing it' taking it on board without having the time to think through why they want to do it, how it fits with other initiatives within the institution's development plan and scheme of values, and what the personal and institutional risks are. (Ruddock and Fielding 2006, p.228)

The lack of clarity means that 'it is not clear whether a more sophisticated engagement with student voice is a seductive re-articulation of institutional insinuation or a genuinely different orientation to what we do and how we might do it' (Fielding 2006, p.304). 
Fielding's model, like Arnstein's, posits a continuum of student power. At one end 'student voice is largely in passive mode and only audible through the products of past performance'. At the other end 'student voice is the initiating force in an enquiry process which invites teachers' involvement as facilitating and enabling partners in learning' (Fielding 2004, p.201). Fielding's model presents six progressively empowering levels of student engagement: students as data source, students as active respondents, students as coenquirers, students as knowledge creators, students as joint authors, and 'intergenerational learning as lived democracy' (Fielding 2012, p.50). At each level there is an intention for students to be involved in decision-making but there are very different implications for the balance of power. When students are treated as data sources the power resides almost entirely with the school and the staff, whereas when they act as knowledge creators, '[i]t is students who identify the issues to be pursued and students who subsequently undertake the enquiry/development with the support of staff' (Fielding 2012, p.52). At the highest levels, for Fielding, there is a 'genuinely shared, fully collaborative partnership', and a 'joint commitment to the common good' (Fielding 2012, p.53).

Although developed for school education, Fielding's model has been widely cited in literature on student engagement in higher education (Cook-Sather 2010, Robinson 2012, Cohen et al 2013, Freeman et al 2013, Seale et al 2015). A number of researchers (Seale 2010, Carey 2013, Freeman 2014) have developed substantial applications of his model to higher education. Seale (2010) sees value in Fielding's conceptualisation of student voice work 'as empowerment (through the countering of oppression) and transformation' (Seale 2010, p.1001), and she applies his model to participatory research methods in order to explore the idea of 'speaking with rather than for students' (p.1001). Carey (2013) seeks to adapt Fielding's model to explore student representative processes and how they can 'offer opportunities for active engagement and radical collegiality' (p.72).

Fielding himself is opposed to neoliberal approaches to education: 'the application of market models to the public realm...disrupts and distorts the very basis of our well-being as citizens and as persons' (Fielding 2004, pp.197-8). He also complains about specific elements of neoliberalism, in particular the 'deeply dull and destructive discourse of 
performativity' (Fielding 2001, p.133). It is clear that the model itself has an intrinsic antineoliberal alignment. The lower quality forms of engagement are equated to neoliberal approaches. They 'tend to emphasise a range of different ways in which students can be consulted' (Fielding 2004, p.203), and he worries that consulting students will prove to be 'a tokenistic nod in the direction of consumerism' (Ruddock and Fielding 2006, p.229).

The higher forms of engagement, on the other hand - the relationships of partnership and 'radical collegiality' that go beyond consultation - involve a rejection of neoliberalism. They 'transcend the now ubiquitous intrusions of the market' (Fielding 2012, p.54), are 'explicitly egalitarian' (Fielding 2012, p.57) and 'challenge the domination of neoliberal perspectives' (Fielding 2012, p.58).

This section has described two of the most prominent models used to conceptualise student engagement as students' participation in decision-making. They both embody a rejection of neoliberal approaches to higher education; both Arnstein and Fielding envisage a progression from better to worse citizen/student participation where the preferred modes of participation are expressed in explicitly progressive, democratic and egalitarian terms.

\section{Conclusion}

Nick Zepke believes that there is an important alignment between research on student engagement and neoliberal ideas about higher education. He believes that the literature on student engagement reflects and supports a focus on performativity, marketization and commodification. He allows that there are some researchers that buck the trend, but claims that in the main research on engagement props up the neoliberal takeover of higher education. Paul Trowler objects to a number of Zepke's claims, but he ultimately agrees that student engagement literature that critiques neoliberal approaches is in the minority.

Both Zepke and Trowler attempt to be inclusive in their reading of the engagement literature. Nevertheless, they both focus on literature that addresses student engagement understood as students' participation in various forms of active learning. This literature is focused around the engagement construct expressed by NSSE, but also includes literature 
on very different topics such as belonging (Thomas 2012), transformational learning (Barnett and Coates 2005) and radical pedagogies (Neary 2013). However there is a substantial alternative body of literature on student engagement, that explores students' participation in decision-making. It is concerned with issues like feedback, representation, and involvement in curriculum design, and is closely related to the concepts of student voice and students-as-partners.

Zepke's exploration of the ideological affiliation of engagement research is important for improving our understanding of the concept of student engagement, and for ensuring that its powerful role in policy and practice is critically evaluated. It is the dominant conceptualisation of student engagement in the UK and there is a lack of clarity about the nature of the concept, and whose interests are served by greater participation of students in decision-making. The power of students over learning and teaching decision-making is highly political. Neoliberal approaches give a prominent role to students' views, positioned as consumers in a market system. Opposed approaches - for example from critical pedagogy or the student movement - also give a prominent role to students' views, but position students in very different ways, such as members of a unified academic community, or as an oppressed group within the university society. It is therefore important to be clear about any political alignment of the related field of research. This paper has argued that, in contrast to Zepke's claim about the engagement research that is his focus, the literature on students' participation in decision-making has a bias against neoliberalism. This paper has focused on two of the most prominent models that have been used to conceptualise student participation in decision-making. Persuasively characterising a body of literature with respect to something largely implicit like ideological affiliation is a challenge. I have restricted myself to a narrower but more concrete claim: that any literature on student participation in decision-making that substantially relies on the models of Arnstein or Fielding contains an ideological opposition to neoliberal approaches to higher education. None of this contradicts Zepke's claim, and this paper has consisted of an extension to his enquiry rather than a direct engagement with his position.

One of Zepke's claims is that researchers on student engagement need to be more aware of the ideological dimension of their work. They need to 'raise their consciousness about the 
political implications of their enterprise' (Zepke 2014, p.704). Zepke is concerned that engagement researchers become more aware of their positive relationship with neoliberal ideas, and to mitigate that relationship, to 'extend their research beyond the marketization and knowledge, performativity, accountability' (Zepke 2014, p.704). The same holds true for the literature that has been the focus of this paper. There should be more explicit discussion of the political implications of research into students' participation in decision-making. Firstly, it could help to add more clarity to the concept of engagement, which is used in a range of competing ways. Secondly, the prominence of student engagement in policy and practice means that engagement research has a powerful reach beyond the literature. At a policy level, the current highly politicised nature of higher education means that clarity about the political implications of engagement research is crucial. At the level of teaching practice, clarity about underlying aims and values is vital to the successful implementation of new ideas.

\section{Acknowledgements}

I would like to thank both anonymous reviewers for comments which helped me to improve key elements of this paper. 


\section{References}

Arnstein, S. (1969). A ladder of citizen participation. Journal of the American Planning Association 35(4): 216-224

Ashwin, P. and McVitty, D. (2015). The Meanings of Student Engagement: Implications for Policies and Practices. In Curaj et al (eds.) The European Higher Education Area (London, Springer): $343-359$

Barnett, R. and Coates, K. (2005). Engaging the curriculum in higher education (Maidenhead, Open University Press)

Baron, P. and Corbin, L. (2012). Student engagement: rhetoric and reality. Higher Education Research \& Development 31(6): 759-772

BIS (2011). Higher education: Students at the heart of the system (London, Department for Business, Innovation and Skills)

Bovill, C. and Bulley, C. (2011). A model of active student participation in curriculum design: Exploring desirability and possibility. In Rust, C. (ed) Improving Student Learning 18: Global theories and local practices (Oxford, Oxford Centre for Staff and Learning Development).

Bovill, C. and Felten, P. (2016). Cultivating student-staff partnerships through research and practice. International Journal for Academic Development 21(1): 1-3

Bovill, C., Bulley, C. and Morss, K. (2011). Engaging and empowering first-year students through curriculum design: perspectives from the literature. Teaching in Higher Education 16(2): 197-209.

Brown, R. (with Casson, H.). (2012). Everything for sale? The marketisation of UK higher education (London, Routledge) 
Bryson, C. and Hamshire, C. (2016). Editors' introduction. Student Engagement in Higher Education Journal 1(1): 1-4

Buckley, A. (2015) How radical is student engagement? (And what is it for?). Student Engagement and Experience Journal 3(2).

Campbell, F. (2007). Hearing the student voice: Enhancing academic professional development through the involvement of students. Educational Developments 8(1): 4-7

Carey, P. (2012). Student engagement: stakeholder perspectives on course representation in university governance. Studies in Higher Education 38 (9): 1290-1304

Carey, P. (2013a). Representation and student engagement in higher education: a reflection on the views and experiences of course representatives. Journal of Further and Higher Education 37(1): 71-88

Carey, P. (2013b) Student as co-producer in a marketised higher education system: a case study of students' experience of participation in curriculum design. Innovations in Education and Teaching International 50(3): 250-260

Carey, P. (2016). The impact of institutional culture, policy and process on student engagement in university decision-making. Perspectives: Policy and Practice in Higher Education

Cohen, J., Cook-Sather, A , Lesnick, A., Alter, A., Awkward, R., Decius,F., Hummer, L., Guerrier, S., Larson, M. and Mengesha, L. (2013). Students as leaders and learners: towards self-authorship and social change on a college campus. Innovations in Education and Teaching International 50(1): 3-13

Cook-Sather, A. (2010). Students as learners and teachers: Taking responsibility, transforming education, and redefining accountability. Curriculum Enquiry 40(4): 555-575 
Fielding, M. (2001). Students as radical agents of change. Journal of Educational Change 2: $123-141$

Fielding, M. (2004). 'New Wave' student voice and the renewal of civic society. London Review of Education 2(3): 197-217

Fielding, M. (2006). Leadership, radical student engagement and the necessity of personcentred education. International Journal of Leadership in Education 9(4): 299-313 Fielding, M. (2012). Beyond student voice: Patterns of partnership and the demands of deep democracy. Revista de Educacion 359: 45-65.

Fredricks, J., Blumenfeld, P. and Paris, A. (2004). School engagement: Potential of the concept, state of the evidence. Review of Educational Research 74: 59-109

Freeman, R. (2014). Student voice: New forms of power and governance in higher education in England (2003-2013), doctoral thesis (Birmingham, University of Birmingham)

Freeman, R. and Dobbins, K. (2011). Are we serious about enhancing courses? Using the principles of assessment for learning to enhance course evaluation. Assessment and Evaluation in Higher Education 38 (2): 142-151

Freeman, R., Millard, L., Brand, S. and Chapman, P. (2013). Student academic partners: Student employment for collaborative learning and teaching development. Innovations in Education and Teaching International 51 (3): 233-243

Hart, R. (1997). Children's Participation: the theory and practice of involving young citizens in community development and environmental care (London, Earthscan)

Healey, M,. Flint, A. and Harrington, K. (2014). Engagement through partnership: Students as partners in learning and teaching in higher education (York, Higher Education Academy) 
Kahu, E. (2013). Framing student engagement in higher education. Studies in Higher Education 38 (5): 758-773

Kuh, G. (2009). The National Survey of Student Engagement: Conceptual and empirical foundations. New Directions for Institutional Research 141 (2): 5-20

Little, B. and Williams, R. (2010). Students' roles in maintaining quality and in enhancing learning: Is there a tension? Quality in Higher Education 16 (2): 115-127

Little, B., Locke, W., Scesa, A. \& Williams, R. (2009). Report to HEFCE on Student Engagement (Bristol, HEFCE)

May, H. and Felsinger, A. (2010). Strategic approaches to disabled student engagement. (York, Higher Education Academy and Equality Challenge Unit)

McCormick, A., Kinzie, J. \& Gonyea, R. (2013). Student engagement: Bridging research and practice to improve the quality of undergraduate education. Higher Education: Handbook of theory and practice 28: 47-92

McCulloch, A. (2009). The student as co-producer: learning from public administration about the student-university relationship. Studies in Higher Education 34 (2): 171-183

McMahon, B. and Portelli, J. (2004). Engagement for what? Beyond popular discourses of student engagement. Leadership and Policy in Schools 3(1): 59-76

Neary, M. (2013). Student as producer: Radicalising the mainstream in higher education. In Dunne, E. and Owen, D. (eds.) The Student Engagement Handbook: Practice in higher education (Bingley, Emerald Group Publishing): 587-602

Neary, M. (2016). Raised Voices: from student engagement to political engagement. Student Engagement in Higher Education Journal 1(1): 1-5 
Nixon, E., Scullion, R. and Hearn, R. (2016). Her majesty the student: marketised higher education and the narcissistic (dis)satisfactions of the student-consumer. Studies in Higher Education

NUS-HEA (2011). Student engagement toolkit (London, National Union of Students)

NUS (2014) A manifesto for partnership (London, National Union of Students)

QAA (2012). Quality code chapter B5: Student engagement (Gloucester, Quality Assurance Agency)

Robinson, C. (2012). Student engagement: What does this mean in practice in the context of higher education institutions? Journal of Applied Research in Higher Education 4(2): 94-108

Ruddock, J. and Fielding, M. (2006). Student voice and the perils of popularity. Educational Review 58(2): 219-231

Seale, J. (2010). Doing student voice work in higher education: an exploration of the value of participatory methods. British Educational Research Journal 36(6): 995-1015

Seale, J., Gibson, S., Haynes, J. and Potter, A. (2015). Power and resistance: Reflections on the rhetoric and reality of using participatory methods to promote student voice and engagement in higher education. Journal of Further and Higher Education 39(4): 534-552

Taylor, P., Wilding, D., Mockridge, A. and Lambert, C. (2012). Reinventing engagement. In Solomonides, I., Reid, A. and Petocz, A. (eds.) Engaging with learning in higher education (Faringdon, Libri): 259-278.

Thomas, L. (2012) Building student engagement and belonging in Higher Education at a time of change: final report from the What Works? Student Retention \& Success programme (London, Paul Hamlyn Foundation) 
Trowler, P. (2015). Student engagement, ideological contest and elective affinity: the Zepke thesis reviewed. Teaching in Higher Education 20(3): 328-229

Trowler, V. (2010). Student engagement literature review (York, Higher Education Academy).

Trowler, V. (2015). Negotiating contestations and 'chaotic conceptions': Engaging 'nontraditional' students in higher education. Higher Education Quarterly 69(3): 295-310

Trowler, V. and Trowler, P. (2010). Student engagement evidence summary (York, Higher Education Academy)

Wimpenny, K. and Savin-Baden, M. (2013). Alienation, agency and authenticity: a synthesis of the literature on student engagement. Teaching in Higher Education 18(3): 311-326

Zepke, N. (2014). Student engagement research in higher education: questioning an academic orthodoxy. Teaching in Higher Education 19(6): 697-708

Zepke, N. (2015a). What future for student engagement in neoliberal times? Higher Education 69(4): 693-704

Zepke, N. (2015b). Student engagement and neoliberalism: mapping an elective affinity. International Journal of Lifelong Education 34(6): 696-709

Zepke, N. (2015c). Student engagement research: thinking beyond the mainstream. Higher Education Research \& Development 34(6): 1311-1323

Zepke, N. and Leach, L. (2010). Improving student engagement: Ten proposals for action. Active Learning in Higher Education 11(3): 167-177 
Figures

Figure 1:

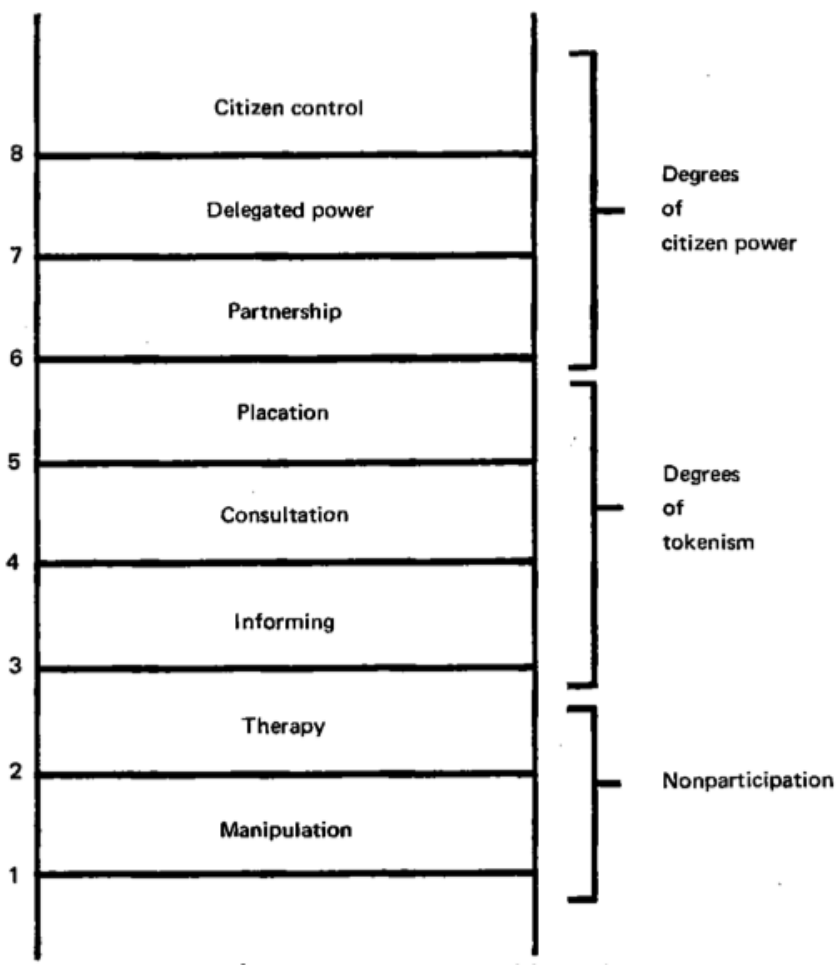


Figure labels

Figure 1: 'Ladder of participation' from Arnstein (1969) 